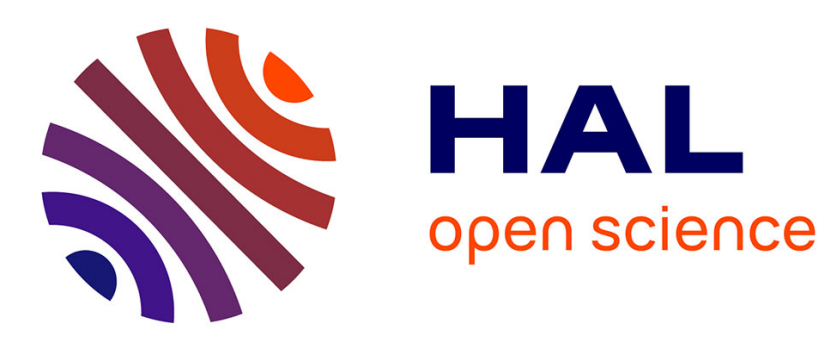

\title{
The myth of concordance: response to Stevenson and Scambler
}

David Armstrong

\section{To cite this version:}

David Armstrong. The myth of concordance: response to Stevenson and Scambler. Health, 2005, 9 (1), pp.23-27. 10.1177/1363459305048092 . hal-00571405

\section{HAL Id: hal-00571405 \\ https://hal.science/hal-00571405}

Submitted on 1 Mar 2011

HAL is a multi-disciplinary open access archive for the deposit and dissemination of scientific research documents, whether they are published or not. The documents may come from teaching and research institutions in France or abroad, or from public or private research centers.
L'archive ouverte pluridisciplinaire HAL, est destinée au dépôt et à la diffusion de documents scientifiques de niveau recherche, publiés ou non, émanant des établissements d'enseignement et de recherche français ou étrangers, des laboratoires publics ou privés. 


\title{
The myth of concordance: response to Stevenson and Scambler
} 1363-4593; Vol 9(1): 23-27

\author{
David Armstrong \\ Kings College London \\ ADDRESS Department of General Practice, 5 Lambeth Walk, London SE11 \\ 6SP, UK. (e-mail david.armstrong@kcl.ac.uk)
}

\section{Introduction}

Stevenson and Scambler's article makes two major claims. The first is that the trust patients have in their doctors has declined in recent years; the second is that, in consequence, concordance, that assumes open communication between doctor and patient, is now becoming impossible to achieve. I will argue that the first claim is unproven (and unprovable) and that the second is correct, but not for the reasons the authors suggest.

\section{Declining trust}

The first two-thirds of the article argues that patients are growing less trusting of their doctors (and health care organizations) than in the past. The claim is made tentatively in the early pages - there is the 'possibility' of declining trust or there 'may' be a decline in trust - but soon crystallizes into more dogmatic statements such as 'The trust people instinctively invested in professional expertise has substantially diminished'. Yet only three pieces of evidence are used to support the claim: the first is a prediction (from one observer) that concerns about health plans in the US would spill over into attitudes towards personal trust between doctor and patient; the second is that there is an increase in litigation against doctors (does this indicate a decline in trust or easier recourse to legal redress?); and the third that there are increased challenges to medical experimentation. None of this evidence is very persuasive that trust in the patient's own doctor has declined. Even less convincing are the supportive comments from others who cling to this article of conventional wisdom. For example, surely the editor of the British Medical Journal should not be taken too literally when he announces with great rhetorical flourish that 'trust will never be the same again' following a report on the latest health care scandal. Did anyone's trust in their medical practitioner change the day after, I wonder? 
The problem of course is that there can be no clinching evidence either way on the decline of trust in medicine since patients have not been systematically consulted on the question over the last century. Indeed, the very idea of eliciting patients' views is little over half a century old (Armstrong, 1984). Yet even the limited evidence from these early studies does not support the idea of a golden age of trust that now is lost. In The Health of Regionsville (Koos, 1954), for example, a quarter of patients expressed dissatisfaction with their last consultation; and in Cartwright's 1967 study of patients and their doctors, less than a quarter of respondents ticked the option that their doctor 'puts (you) at ease, you can talk to him'. Further, only 17-41 percent of patients (depending on age) would be happy to discuss a personal problem with their doctor. And from the 1970s there is the dawning realization that perhaps 50 percent of patients were not taking their medication as advised (building on earlier work on the problem of 'defaulting' from treatment) (Ley, 1982). Such survey findings are not sufficient to show conclusively that trust has not declined but they do imply that the opening argument of this article needs treating with considerable scepticism.

Yet whether or not there really has been a decline in trust seems less important than the conceptual muddle about the relationship of communication to trust, which forms the essential context for the later discussion of concordance. The key argument is taken from Gilson (2003) who argued that 'trust, by keeping minds open to all evidence, secures communication and dialogue'. But, surely, trust is the complete antithesis of this. It is only when there is trust - in a brother, a friend, a child - that there is no need to 'keep minds open to all evidence' as there is no need for suspicion or doubt or need for vigilance for acts of betrayal. Equally, patients would surely have more intensive 'communication and dialogue' with doctors they did not trust than with ones they did ('Thank you doctor, as I trust you I'll just do what you advise'). So, does trust imply communication and dialogue, as argued here? Or should we be persuaded by Mechanic's claim (also endorsed here) that 'patient trust depends on the capacity of clinicians and health organizations to communicate effectively' (Mechanic, 1998: 299), that is, rather than trust securing communication it is good communication that engenders trust? Or maybe the authors want it both ways.

In summary, the article's opening claim seems empirically unsupported (and perhaps untestable) and the form of the relationship of trust with communication uncertain. Nonetheless, the argument of the article depends on such an (empirical) decline in trust and on the belief that declining trust compromises good communication. These assumptions underpin the final discussion on the form and limitations of concordance.

\section{Concordance in context}

The idea of concordance, as the authors point out, was first proposed by Marinker and several colleagues in 1997. Concordance involved 'an open 
exchange of beliefs about medicine about which prescribing and medicinetaking decisions may then be based'. The authors express this ideal of an open exchange in Habermasian terms as 'communicative action' but then insist that as neither party is likely to be entirely open about their views (particularly in view of the supposed decline in trust) the result will, in fact, be 'systemically distorted communication'. A valid point for anyone persuaded that complete openness about views and agendas in consultations is highly unlikely - but who claimed that concordance was a form of communicative action in the first place? There is brief reference to Britten's support for concordance as a means of acknowledging patient autonomy, together with mention of Coulter's advocacy of partnership models in interaction between doctor and patients (though she makes no mention of concordance in her article). Otherwise there is no clear identification of who promotes concordance as this open ideal, even less who believes it to represent communicative action. The article's language is always suggestive: 'the concordance ideal may be presented in terms of the ideal of communicative action' or 'concordance may be interpreted as a call for communicative action' (my emphasis). Are we therefore to understand that it is the authors themselves who are making these presentations and interpretations (before debunking them)? Add to this the knowledge that these two authors figure prominently in the literature that promotes a Habermasian view of the consultation (Barry et al., 2000; Scambler and Britten, 2001) and they seem to be going to curious lengths to attack themselves.

Part of the problem is that concordance is never placed in a wider context that would allow better understanding of its claims Thus concordance's emphasis on sharing views and negotiating (patients') behaviour places it firmly in the 'patient-centred' or 'shared decision-making' genre that emerged in the late 1970s and early 1980s. (Patient-centredness was adapted by Byrne and Long in 1976 from the concept of illness-centredness that had been developed by Balint et al. (1970) some years earlier.) The inventors and proponents of concordance promoted it as a means of establishing a therapeutic alliance between doctor and patient. This agenda reflected contemporary concerns to facilitate shared decision-making in the consultation as a counter to traditional medical dominance. Not only was medical dominance unsuited to a consumerist age in which patients' rights were stressed by political commentators and their autonomy by ethicists, but the old system was thought not to deliver effective health care. As noted, successive studies had shown the wide extent of the problem of noncompliance (recast more recently as non-adherence by psychologists anxious to switch the emphasis from patients' misbehaviour to patients making choices). The task was how to influence patient behaviour.

Shared decision-making had a number of advantages. Sharing decisions addressed the increasing need to recognize patients' rights and autonomy; they might solve the compliance problem as it would encourage patient commitment to a course of action; and in shifting some of the responsibility 
for decisions from doctor to patient they might just relieve the doctor of some clinical, psychological and legal burdens. Concordance was simply one variant of this new approach to consultations. Not only was concordance involved with shared decision-making but also in the view that a shared decision secured the patient's subsequent behaviour: an agreement to take or not to take medication implied the patient would follow the agreed course of action (though again the empirical basis for this assumption is far from established).

In effect, the concept of concordance emerged at the confluence of a number of different streams of political and clinical events. Concordance gave patients shared decision-making and a consumer status in the doctor-patient relationship; as noted, concordance might even have persuaded the patient to take their medicines; and concordance had some advantages for the doctor both in terms of more rewarding consultations and decreased responsibility for taking on the burden of patients' illnesses. The concept of concordance was therefore an ideal solution to a number of late-20th-century clinical problems. This means it can be cast in either a positive or negative light, as either a liberating device (as in communicative action) that gives power to the patient or, more cynically, as yet another pernicious attempt by medicine to get the patient to behave according to the doctor's own wishes. The latter of course needs to conceal its purpose by masquerading as the former. So let us not get starry-eyed about concordance. The main goal of many (most?) of its proponents is to get patients to take their medicines as directed, or at least not waste them. Arguments in favour of concordance are consistently embedded in discussion of the compliance 'problem' (which is of course a problem for paternalistic medicine, not for patients who simply decide for themselves whether to take their medicine as directed or not). Look at the publications on the 'Medicines Partnership: from compliance to concordance' website (http://www.medicines-partnership.org) or note the telling title of a recent report from the UK House of Commons All-party Pharmacy Group, 'Concordance and wasted medicines'. Concordance is fast becoming the acceptable face of compliance: the goals remain the same but the technique is more subtle as patients are recruited to direct themselves in medicine-taking. Could this ever have been communicative action? To present a romantic and idealized view of the potential of concordance and then to claim this dream has gone because trust has gone is simply to create and then destroy a straw man. Concordance never could have been what these authors clearly wish it had been.

\section{References}

Armstrong, D. (1984). The patient's view. Social Science and Medicine, 18, 737-44.

Balint, M., Hunt, J., Joyce, D., Marinker, M. and Woodcock, J. (1970). Treatment or diagnosis: a study of repeat prescriptions in general practice. London:

Tavistock. 
Barry, C.A., Bradley, C.P., Britten, N., Stevenson, F.A. and Barber, N. (2000). Patients' unvoiced agendas in general practice consultations: qualitative study. British Medical Journal, 320, 1246-50.

Byrne, P.S. and Long, B.E.L (1976). Doctors talking to patients: a study of the verbal behaviour of general practitioners consulting in their surgeries. London: HMSO.

Cartwright, A. (1967). Patients and their doctors. London: Routledge \& Kegan Paul.

Gilson, L. (2003). Trust and the development of health care as a social institution. Social Science and Medicine, 56, 1453-68.

Koos, E.L. (1954). The health of regionsville: what the people thought and did about it. New York: Hafner.

Ley, P. (1982). Satisfaction, compliance and communication. British Journal of Clinical Psychology, 21, 241-54.

Marinker, M., Blenkinsopp, A., Bond, C., Britten, N., Feely, M., George, C. et al. (1997). From compliance to concordance. Achieving shared goals in medicine taking. London: Royal Pharmaceutical Society of Great Britain.

Mechanic, D. (1998). Public trust and initiatives for new health care partnerships. The Milbank Quarterly, 76, 281-302.

Scambler, G. and Britten, N. (2001). System, lifeworld and doctor-patient interaction, issues of trust in a changing world. In G. Scambler, (Ed.), Habermas, Critical Theory and Health. London: Routledge

\section{Author biography}

DAVID ARMSTRONG is Reader in Sociology as applied to Medicine. He is the author of Political anatomy of the body: medical knowledge in Britain in the twentieth century (Cambridge, 1983) and A new history of identity: a sociology of medical knowledge (Palgrave, 2002). 